\title{
ANALISIS PEMAHAMAN SISWA TERHADAP STRATEGI VISUALISASI, AUDITORI, KINESTETIK
}

\author{
Muhammad Syahrul Kahar ${ }^{1}$, Muhamad Ruslan Layn², \\ Suci Ristiya Nurjanah ${ }^{3}$ \\ ${ }^{1,2,3}$ Program Studi Pendidikan Matematika, Universitas Muhammadiyah Sorong \\ muhammadsyahrulkahar@gmail.com¹, ruslanlayn56@gmail.com², \\ ristiyasuci@gmail.com ${ }^{3}$
}

\begin{abstract}
ABSTRAK
Permasalahan yang muncul dalam proses pembelajaran, siswa belum mampu menjabarkan secara langsung materi yang diajarkan oleh guru, baik secara Visual maupun Kinestetik. Tujuan penelitian ini adalah (1) untuk mengetahui hasil dari penggunaan strategi Visualisasi, Auditori, Kinestetik terhadap pemahaman siswa kelas VIII B pada materi fungsi dan (2) untuk mengetahui respon dari siswa terhadap strategi pembelajaran tersebut. Subjek penelitian ini adalah siswa kelas VIII B MTs Sains Algebra Kota Sorong tahun pelajaran 2017/2018 yang berjumlah 24 orang. Metode pengumpulan data yang digunakan dalam penelitian ini adalah metode observasi, angket, tes dan dokumentasi. Teknik analisis data yang digunakan dalam penelitian ini adalah analisis deskriptif kualitatif. Dari hasil penelitian menunjukan bahwa: (1) hasil dari penggunaan strategi pembelajaran Visualization, Auditory, Kinestetic terhadap pemahaman siswa kelas VIII B MTs Sains Algebra Kota Sorong pada materi fungsi adalah 70\% siswa memperoleh nilai tes di atas KKM, dan $30 \%$ siswa memperoleh nilai tes di bawah KKM. (2) Respon siswa terhadap strategi pembelajaran Visualization, Auditory, Kinestetic adalah sebagai berikut: (a) Untuk pernyataan positif, 46,3\% menyatakan sangat setuju, 42,5\% setuju, 9\% tidak setuju dan $2,2 \%$ sangat tidak setuju. (b) Untuk pernyataan bernilai negatif, $49,1 \%$ menyatakan sangat tidak setuju, 36,7\% tidak setuju, $11,7 \%$ setuju dan $2,5 \%$ sangat setuju.
\end{abstract}

Kata kunci: auditori, kinestetik, pemahaman siswa, visualisasi

\begin{abstract}
Problems that arise in the learning process, students have not been able to describe directly the material taught by teachers, both in Visual and Kinestetik. The purpose of this research is for: (1) to knowing the results of the use of Visualization, Auditory, Kinestetic Strategy to student comprehension of Class VIII B on the function matery, and (2) to knowing student respons to the strategy. The subject in this research is student of Class VIII B MTs Sains Algebra Kota Sorong year 2017/2018 which is amounted to 24 student. Method of collecting data that used in this research is observation methods, questionnaire, test and documentation. Data analysis technique that used in this research is qualitative descriptive analysi. Based on the research showing that: (1) the results of the use of Visualization, Auditory, Kinestetic Strategy to student comprehension class VIII B on the function matery is $70 \%$ student got skores above the KKM, and $30 \%$ student got skores below the KKM. (2) student respons to the use of Visualization, Auditory, Kinestetic Strategy is: (a) for positive statements: 46,3\% stated very agree, , 42,5\% agree, $9 \%$ disagree and 2,2\% very disagree. (b) for negative statements: 49,1\% stated very disagree, $36,7 \%$ disagree, $11,7 \%$ agree and $2,5 \%$ very agree.
\end{abstract}

Keywords: auditory, kinestetic, student comprehension, visualization 


\section{PENDAHULUAN}

Istilah efektif dalam kegiatan belajar menurut Uno dan Mohamad (2015:173) adalah bahwa pembelajaran dikatakan efektif apabila skor yang dicapai Siswa memenuhi batas minimal kompetensi yang telah dirumuskan. Standar kompetensi yang dimaksudkan adalah tercapainya kriteria ketuntasan belajar siswa selama mengikuti proses pembelajaran di kelas. Rumusan kompetensi ini bukan saja dalam tataran teoritis tetapi harus terimplikasi dalam kehidupannya. Untuk itu, sebagai guru tentu sangat mengharapkan keefektifan pembelajaran dapat dicapai dengan baik.

Salah satu aspek yang perlu dikembangkan oleh Siswa dalam proses pembelajaran untuk mendapatkan prestasi belajar yang ingin dicapai adalah gaya belajar, karena gaya belajar merupakan kunci utama bagaimana seseorang bisa mengembangkan kemampuan yang dimiliki (Khoiri et.al, 2017). Strategi VAK (Visualisasi, Auditori, Kinestetik) adalah strategi pembelajaran yang memanfaatkan potensi yang telah dimiliki siswa dengan melatih dan mengembangkannya. Strategi VAK memfokuskan pembelajaran pada pemberian pengalaman secara langsung (direct experience) dan menyenangkan (fun). Pengalaman belajar secara langsung dilakukan dengan cara; belajar dengan melihat (visual), belajar dengan mendengar (audiotory) dan belajar dengan gerak dan emosi (kinestetik).

Gaya belajar visual (belajar dengan cara melihat) umumnya disebut sebagai gaya belajar pengamatan. Gaya belajar ini sangat mengandalkan indra penglihatan atau mata dalam proses pembelajaran (Suparman, 2010: 66). Gaya belajar ini mengakses citra visual yang diciptakan maupun diingat misalnya warna, hubungan ruang, potret, mental, dan gambar menonjol. Siswa visual lebih cenderung untuk mengingat informasi dengan menyaksikan langsung sumber informasi tersebut. Mata merupakan indra yang paling dominan dalam proses pembelajaran pada anak visual, oleh karena itu metode pembelajaran yang diterapkan oleh guru harus menitikberatkan pada alat peraga atau media visual, membawa mereka pada objek-objek yang berkaitan dengan pelajaran, atau bisa juga dengan cara menggambarkannya di papan tulis. 
Gaya belajar audiotorial (belajar dengan cara mendengar) adalah gaya belajar yang memanfaatkan indera pendengaran untuk mempermudah proses belajar. gaya belajar ini lebih menekankan pada indra pendengar (telinga) dalam proses penyerapan informasi (Suparman, 2010: 66). Selain itu, Siswa yang mempunyai gaya belajar audiotorial dapat mencerna makna yang disampaikan melalui suara, dan hal-hal auditori lainnya. oleh karena itu, siswa yang mempunyai hal demikian lebih mudah berdiskusi verbal dan mendengarkan apa dikatakan, serta lebih termotivasi dalam pembelajaran.

Gaya belajar kinestetik (belajar dengan cara bergerak, bekerja, dan menyentuh) biasanya disebut juga sebagai gaya belajar penggerak. Oleh karenanya gaya belajar ini senantiasa menampakkan gerakanbadan dalam pembelajaran untuk memahami apa yang dilihat dan dilakukan (Suparman, 2010: 68-69). Gaya belajar kinestetik mengakses segala jenis gerak dan emosi diciptakan maupun diingat. Gerakan, koordinasi, irama, tanggapan emosional dan kenyamanan fisik, Siswalebih suka bergerak, dan merasakan atau mengalami sendiri, gerakan tubuh (aktivitas fisik), sehingga mampu untuk memahami apa yang dikerjakan.

Pemahaman merupakan bentuk dari sebuah kemampuan guna menangkap sebuah makna yang tersirat terhadap apa yang dipelajari, kemudian diuraikan ke dalam suatu inti pembahasandan mampu untuk memigrasi data yang disajikan dalam bentuk tertentu ke bentuk yang lain. Lebih baik lagi apabila siswa tersebut dapat memberikan contoh atau mensinergikan apa yang dipelajari dengan permasalahan-permasalahan yang ada di sekitarnya

Permasalahan yang kemudian muncul adalah siswa belum mampu menjabarkan secara langsung materi yang diajarkan oleh guru, baik secara Visual maupun Kinestetic. Hal lain yang terjadi siswa masih sangat perlu pembelajaran yang berorientasi pada kondisi realitas dilapangan baik dalam bentuk praktik atau pun strategi pembelajaran lainnya. Oleh karenanya perlu diterapkan metode atau strategi pembelajaran dengan menggunakan Visualisasi, Auditori, Kinestetik (VAK) yang dianggap mampu untuk memproyeksikan ketiga gaya belajar tesebut. Selanjutnya akan dianalisis hasil dari penggunaan strategi pembelajaran VAK terhadap pemahaman siswa pada materi fungsi, dan juga bagaimana respon siswa 
terhadap pembelajran yang menggunakan strategi tersebut. Adapun tujuan dari pelaksanaan penelitian ini adalah untuk mengetahui hasil dari penggunaan strategi Visualisasi, Auditori, Kinestetik terhadap pemahaman siswa dan untuk mengetahui respon dari siswa terhadap strategi pembelajaran.

\section{METODE PENELITIAN}

Pendekatan deskriptif kualitatif dipilih untuk menunjang proses penelitian kualitatif ini, karena data yang dikumpulkan adalah berupa kata-kata, gambar, dan bukan angka-angka. Penelitian ini dilakukan di MTs Sains Algebra Kota Sorong pada semester ganjil tahun pelajaran 2017/2018 berjumlah 24 siswa. Dalam proses pengumpulan data, digunakan metode observasi, angket, tes, dan dokumentasi, yang pada akhirnya hasil dari keseluruhan metode tersebut akan menghasilkan data yang dipaparkan secara deskriptif. Teknik Analisis data dalam penelitian ini dengan menggunakan Excel yang dilakukan untuk menganalisis hasil belajar secara deskriptif, observasi Aktivasi dan validasi. Untuk observasi aktivitas didasarkan pada tabel 1 sebagai berikut:

Tabel 1. Penilaian Aktivitas

\begin{tabular}{cc}
\hline Persentase \% & Kriteria \\
75 & Sangat aktif \\
65 & Aktif \\
55 & Cukup aktif \\
0 & Kurang aktif \\
\hline
\end{tabular}

Dengan persamaan sebagai berikut:

$$
\% \text { Keaktifan }=\frac{\text { Skor yang diperoleh }}{\text { Skor maksimum }} \times 100
$$

\section{PEMBAHASAN}

Pelaksanaan penelitian ini, terlebih dahulu melakukan validasi instrumen penelitian. Validasi ini digunakan untuk mendapatkan instrumen penelitian yang berkriteria valid. Hasil validasi instrumen yang oleh validator 1 dan validator 2 , dapat dilihat pada diagram di bawah ini: 


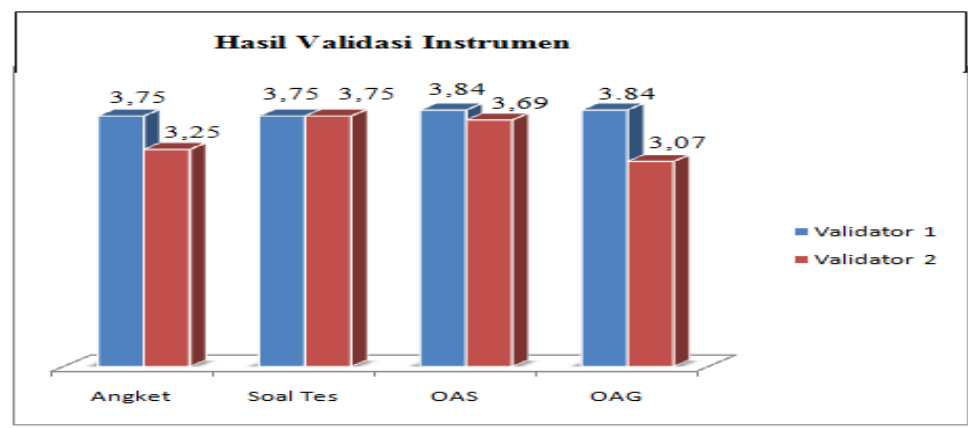

Gambar 1. Histogram Hasil Validasi

Pada Gambar 1 menunjukan hasil validasi dari validator 1 dan validator 2. Untuk validasi angket diperoleh nilai rata-rata yaitu: 3, 75 dari validator 1 dan 3,25 dari validator 2. Dengan rata-rata skor maksimum perolehan 4, sehingga angket respon Siswa dinyatakan dapat dipakai untuk penelitian dengan revisi kecil (valid). Sementara hasil validasi soal tes dari validator 1 rata-rata adalah 3,75 dan dari validator 2 adalah 3,75. Dengan rata-rata skor maksimum perolehan 4, sehingga soal tes dinyatakaan valid dan dapat dipakai untuk penelitian. Hasil validasi Observasi Aktivitas Siswa dan Observasi Aktivitas Guruoleh validator 1 berturut-turut adalah 3,84 dan 3,84, sedangkan oleh validator 2 sebesar 3,69 dan 3,07 dengan skor maksimum 4 maka lembar OAS dan lembar OAG dapat dipakai untuk penelitian dengan revisi kecil (valid).

Berdasarkan hasil uji coba penelitian dari 24 orang Siswa, maka temuan penelitian tentang pemahaman siswa sebagai berikut:

\section{Hasil Tes}

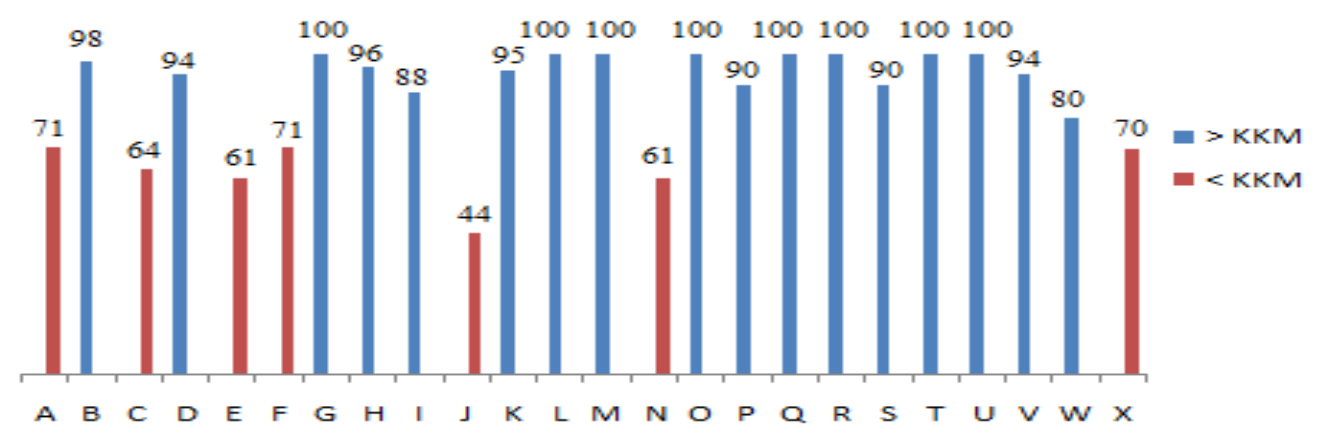

Gambar 2. Hasil Tes Siswa 
Gambar di atas memuat nilai hasil tes Siswa kelas VIII B yang berjumlah 24 orang, dimana dapat dilihat bahwa: 8 orang Siswa mendapatkan nilai 100, 1 orang mendapatkan nilai 98, 1 orang mendapatkan nilai 96, 1 orang mendapatkan skor 95, 2 orang mendapatkan nilai 94, 2 orang mendapatkan nilai 90, 1 orang mendapatkan nilai 88,1 orang mendapatkan nilai 80,2 orang mendapatkan nilai 71,1 orang mendapatkan nilai 70,1 orang mendapatkan nilai 64,2 orang mendaptkan nilai 61 , dan 1 orang mendapatkan nilai 44. Mengingat KKM (Kriteria Ketuntasan Mengajar) yang telah ditetapkan oleh pihak sekolah untuk mata pelajaran matematika kelas VIII adalah 73, maka dapat disimpulkan bahwa: $70 \%$ dari Siswa (17 orang) memperoleh nilai di atas KKM $(\geq 73)$ dan 30\% dari Siswa (7orang) memperoleh nilai di bawah KKM $(<73)$.

Selanjutnya untuk keperluan analisis data maka akan diambil hasil tes siswa sebagai sampel penelitian. Sampel yang diambil adalah hasil tes dari siswa yang nilainya di bawah KKM $(<73)$. Berikut akan dianalisis hasil tes siswa yang nilainya belum memenuhi KKM.
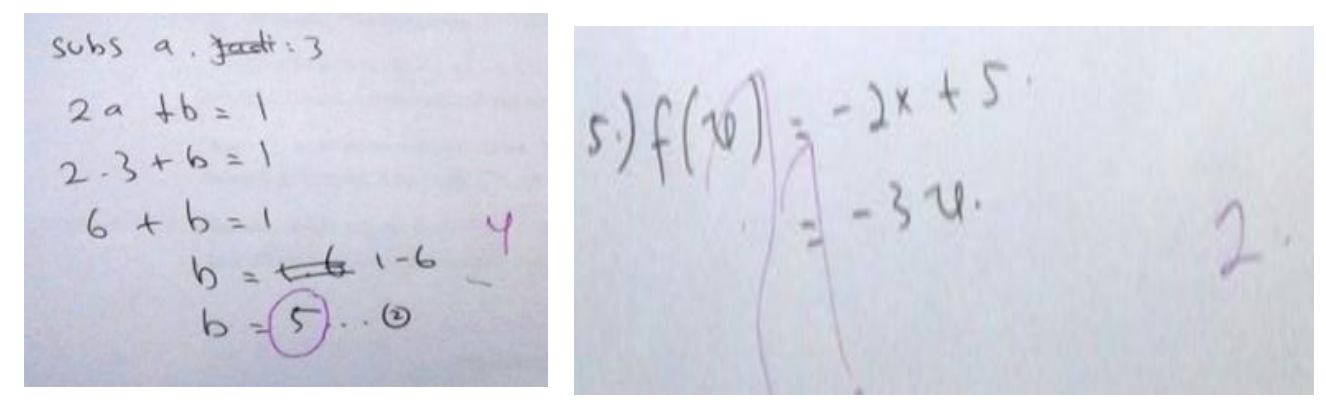

Gambar 3. Bentuk Analisis Kesalahan Pemahaman Siswa

Gambar 3 adalah kekeliruan yang dilakukan siswa pada soal no 4 dan pada soal nomor 5. Kekeliruan yang terjadi pada umumny adalah Siswa belum mampu melakukan operasi bilangan bulat khususnya operasi antara bilangan positif dengan bilangan negatif. Selanjutnya siswa belum mampu menentukan nilai fungsi untuk setiap nilai $\mathrm{x}$ jika diketahui daerah domainnya. Hal ini dikarenakan pada soal tersebut digunakan untuk menentukan nilai fungsi untuk setiap nilai x jika diketahui daerah domainnya, caranya adalah dengan melakukan proses substitusi untuk setiap nilai x pada rumus fungsi, sehingga akan didapat nilai fungsi untuk setiap $\mathrm{x}$. oleh karena itu siswa harus mampu memahami materi 
yang diajarkan terlebih dahulu, lalu menganalisis setiap substansi pertanyaan dari setiap soal yang diberikan

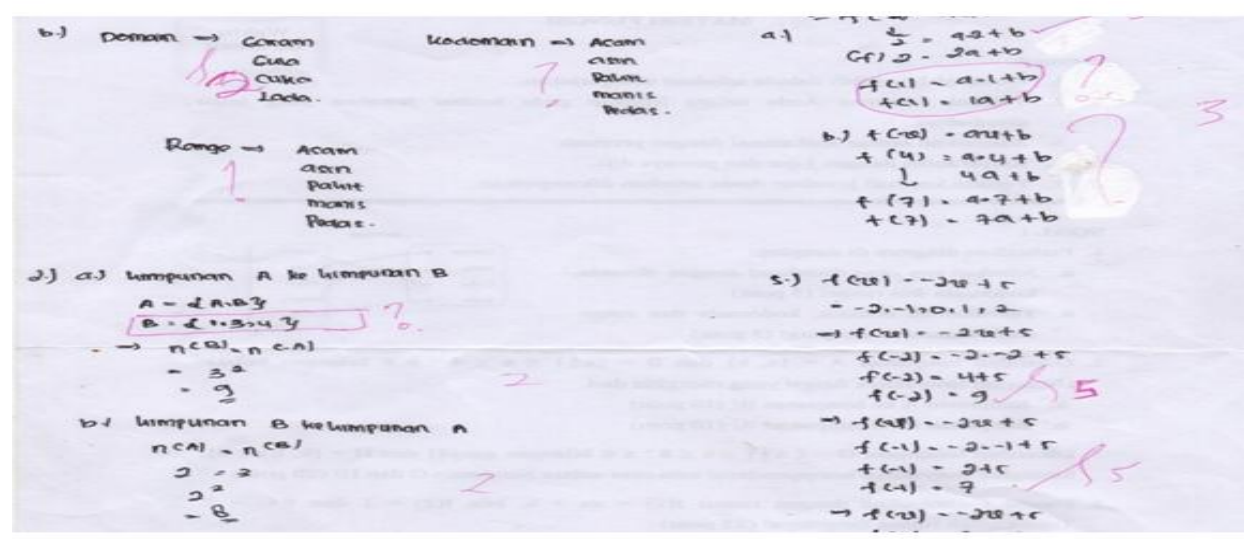

Gambar 4. Bentuk Analisis Kesalahan Pemahaman Siswa

Gambar di atas merupakan analisis hasil tes siswa dengan perolehan skor 64 (di bawah KKM). Dari kutipan tersebut dapat diketahui bahwa pada soal nomor 1 Siswa kesulitan dalam menentukan anggota dari domain, kodomain dan range, pada soal nomor 2 siswa belum mampu menentukan banyaknya fungsi yang mungkin dari dua himpunan, dan pada soal nomor 4 siswa belum mampu mentukan atau mencari rumus dari suatu fungsi. Selanjutnya adalah kekeliruan yang dilakukan oleh siswa yang mendapat perolehan skor 42 .

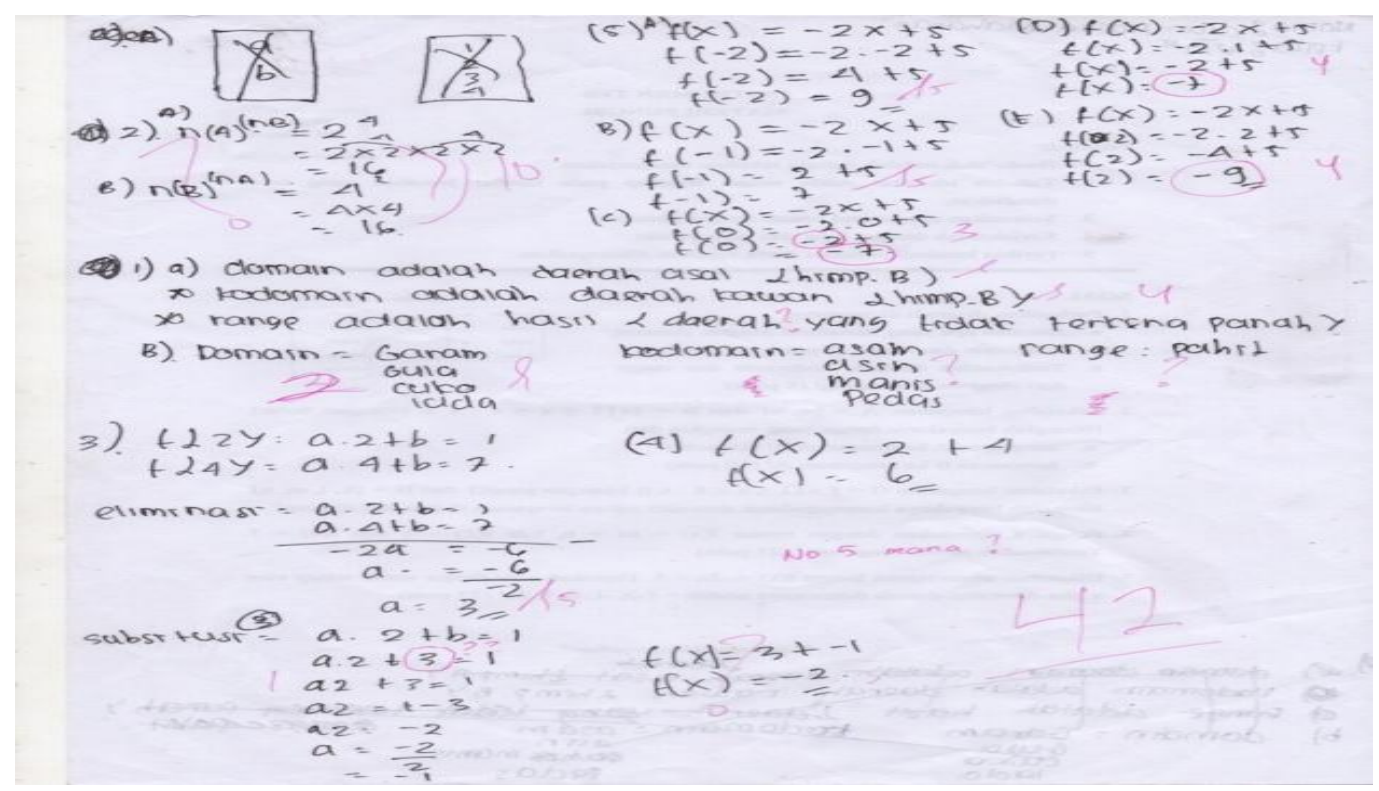

Gambar 5. Bentuk Analisis Kesalahan Pemahaman Siswa 
Dari Gambar 5 dapat diketahui bahwa pada soal nomor 1 siswa mengalami kesulitan dalam menentukan anggota dari domain, kodomain dan range. Kemudian pada soal nomor 2 siswa belum mampu menentukan banyaknya fungsi yang mungkin dari dua himpunan. Pada hasil analisis tes siswa, terdapat beberapa kekeliruan yaitu:

1) Untuk poin a, dalam menentukan banyaknya fungsi yang mungkin dari himpunan A ke B bukan dengan rumus tersebut, melainkan adalah dengan menggunakan rumus $\mathrm{n}(\mathrm{B})^{\mathrm{n}(\mathrm{A})}$

2) Untuk poin dalam menentukan banyaknya fungsi yang mungkin dari himpunan B ke A bukan dengan rumus tersebut, melainkan adalah dengan menggunakan rumus $\mathrm{n}(\mathrm{A})^{\mathrm{n}(\mathrm{B})}$. Sedangkan pada soal nomor 3 Siswa melakukan kekeliruan dalam proses substitusi sehingga mempengaruhi hasil akhir (lihat gambar 6)

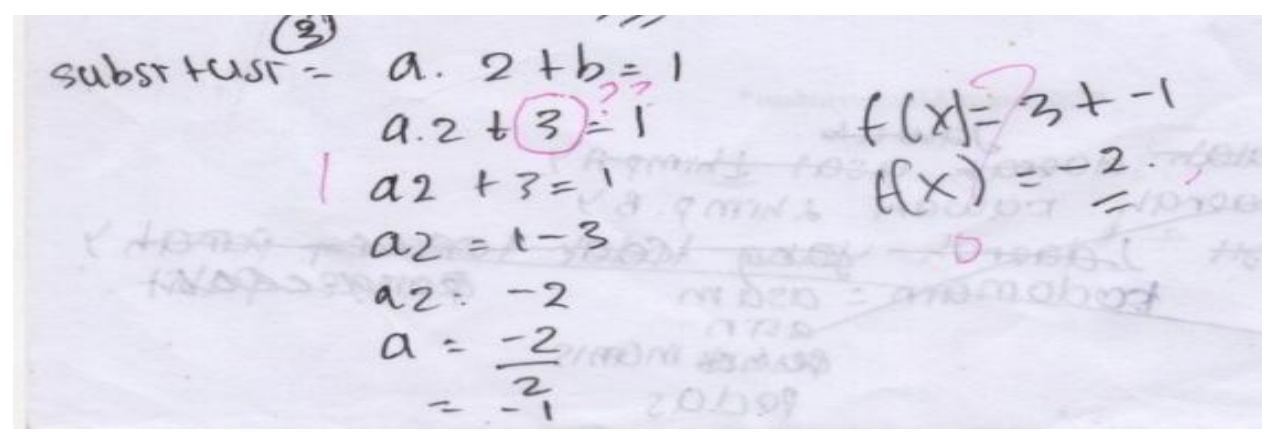

Gambar 6. Bentuk Kekeliruan pada soal No. 3

\section{HASIL PENELITIAN}

Jika dianalisa lebih lanjut presentase pemamahan siswa terhadap setiap sub materi adalah sebagai berikut: untuk sub materi fungsi, kodomain, domain, dan range presentasenya adalah sebesar: $83,33 \%$. Presentase pemahaman siswa terhadap sub materi fungsi korespondensi satu-satu adalah sebesar: 95,83\%. Presentase pemahaman siswa terhadap sub materi banyak fungsi yang mungkin dari dua himpunan adalah sebesar: 83,33\%. Presentase pemahaman Siswa terhadap sub materi menentukan rumus fungsi adalah sebesar: 75\%. Presentase pemahaman siswa terhadap sub materi menentukan rumus fungsi adalah sebesar: 50\%. Hal ini sejalan dengan penelitian Kahar (2017) yang menyatakan bahwa kemampuan siswa dalam memahami dan menganalisis sebuah soal sangat berpengaruh terhadap prestasi belajar dan atau hasil belajar yang diperoleh. 
Dari 24 angket yang telah diisi oleh siswa, temuan tentang respon siswa terhadap strategi pembelajaran VAK adalah untuk pernyataan bernilai positif, 46,3\% Siswa menyatakan sangat setuju, 42,5\% menyatakan setuju, 9\% menyatakan tidak setuju dan 2,2\% menyatakan sangat tidak setuju. Sementara untuk pernyataan yang bernilai negatif yaitu: $49,1 \%$ siswa menyatakan sangat tidak setuju, 36,7\% menyatakan tidak setuju, 11,7\% menyatakan setuju, dan 2,5\% menyatakan sangat setuju.

Sementara bila dikaitkan dengan aktivitas siswa selama proses pembelajaran VAK berlangsung, dimana data aktivitas ini diambil melalui lembar observasi aktivitas yang telah ada pada guru dengan melihat skor yang diperoleh oleh siswa, sehingga temuan ini menunjukkan bahwa aktivitas siswa pada kriteria sangat aktif. Hal ini terindikasi dari hasil observasi yang dilakukan selama proses pembelajaran, mulai dari pertemuan awal hingga pertemuan akhir. Hasil analisis aktivitas siswa menunjukan perolehan skor yang didapat siswa mengalami peningkatan setiap waktunya, sejalan dengan Kahar (2017) menjelaskan bahwa minat siswa dalam belajar sangat berpengaruh terhadap peningkatan aktivitas proses pembelajaran di kelas, sehingga luaran pembelajaran menjadi jauh lebih baik.

\section{SIMPULAN}

Setelah melakukan kajian teoritis dan analisis data, maka dapat disimpulkan bahwa: Hasil dari penggunaan strategi pembelajaran VAK terhadap pemahaman Siswa pada materi fungsi adalah rata pencapaian yang diperoleh oleh siswa selama proses pembelajaran dengan menggunakan Visualisasi, Auditori, Kinestetik (VAK) mampu mengembangkan proses berpikir dan pemahaman siswa terhadap materi yang diajarkan dengan persentase rata-rata sebesar 70\% Siswa memperoleh nilai tes di atas KKM, dan $30 \%$ siswa memperoleh nilai tes di bawah KKM. Selain itu, aktivitas siswa terhadap penggunaan Visualisasi, Auditori, Kinestetik berada pada kategori aktif dan sangat aktif. Hal ini memicu semangat siswa untuk terus belajar dalam meningkatkan pemahaman terhadap materi. Oleh sebab itu, perlu ada pola pembelajaran yang lebih mengaitkan pada Visualisasi, Auditori, Kinestetik sehingga mampu merangsang siswa untuk 
berpikir secara nyata dan siswa mampu mengaitkan materi tersebut dengan kondisi dalam kehidupan sehari-hari.

\section{DAFTAR PUSTAKA}

Baharuddin, \& Esa Nur Wayuni. 2015. Teori Belajar \& Pembelajaran. Yogyakarta: Ar-Ruzz Meia.

Deporter, Bobbi \& Hernacki, Mike. 1992. Quantum Learning. Terjemahan oleh Alwiyah Abdurrahman. 2010. Bandung: Kaifa.

Deporter, Reardon, dan Nourie. 1999.Quantum Teaching. Terjemahan oleh Ary Nilandari. 2010. Bandung: Kaifa.

Kahar, M. S. (2017). Analisis Kemampuan Berpikir Matematis Siswa SMA kota Sorong terhadap Butir Soal dengan Graded Response Model. Tadris: Jurnal Keguruan dan Ilmu Tarbiyah, 2(1), 11-18.

Kahar, M. S. (2017). Analisis Minat Belajar Mahasiswa Terhadap Penggunaan Alat Peraga Neraca Cavendish. SEJ (Science Education Journal), 1(2), 7383.

Khoiri, A., Nasihah, U., \& Kahar, M. S. (2017). Analisis Prestasi Belajar Fisika Berpendekatan SETS di Tinjau dari Motivasi Berprestasi. Jurnal Riset dan Kajian Pendidikan Fisika, 4(2), 83-89.

Lona, Defri, Yanto. 2013. Analisis Hirarki Pemahaman Siswa Kelas X-A SMA Negeri 5 Palu Pada Materi Hukum Newton, (Online), http://jurnal.untad. ac.id. (diakses tanggal 06 Agustus 2017)

Mahanani, Tri. 2007. Analisis Pemahaman Konsep Kimia Pada Materi Pokok Sistem Periodik Unsur Siswa Kelas X Program Imersi Semester Gasal SMA Negeri 4 Surakarta Tahun Pelajaran 2006/2007, (Online), http://dglib.uns. ac.id/pengguna.php?mn=showview\&id=4114, (diakses tanggal 06 Agustus 2017)

Maiyetri, Ressy. 2014. Pengaruh Gaya Belajar Visual, Gaya Belajar Auditorial, Dan Kemampuan Berpikir Kritis Terhadap Prestasi Belajar Siswa Kelas XII IPS Pada Mata Pelajaran Ekonomi di SMA Negeri 8 Padang. http://ejournal.stkippgrisumbar.ac.id/index.php/economica/article/view/20 (diunduh tanggal 05 Agustus 2017).

Uno, Hamzah B. \& Mohamad, Nurdin. 2015. Belajar dengan Pendekatan PAIKEM: Pembelajaran Aktid, Inovatif, Lingkungan, Kreatif, Efektif dan Menarik. Cet. Ke-6. Jakarta: Bumi Aksara.

Suparman. 2010. Gaya Mengajar yang Menyenangkan Siswa. Yogyakarta: Pinus Book Publisher.

Sugiyono. 2014. Metode Penelitian Kuantitatif, Kualitatif, Research \& Development. Cet. Ke-21. Bandung: Alfabeta. 